\title{
The older person in hospital: Do not lose the teddy bear
}

\author{
MA Gosney* \\ Royal Berkshire NHS Foundation Trust, Elderly Care Medicine, London Road, Reading, Berkshire, RG1 5AN, United Kingdom
}

\section{Background}

The teddy bear may be a useful clinical sign both diagnostically and therapeutically in patients of various ages. Teddy bears are increasingly seen in Elderly Care Medicine Units but is there evidence of therapeutic value in this age group?

Evidence from Paediatric literature shows that a "breathing" teddy bear in contrast so a "non-breathing" bear results in babies having slower and more regular respiration during quiet sleep. This effect persists for up to twelve weeks in premature infants born at thirty-three weeks [1].

Teddy bears provide comfort and reassurance during periods of isolation in older children [2]. Even at the age of two, a girl will be upset when a boy plays with her teddy bear without permission but not when he plays with his own. Therefore, ownership is useful in predicting basic emotions particularly during violations of ownership rights [3]. Teddy bears have also been used for teaching children coping strategies prior to medical procedures [4].

The teddy bear sign in neurology is when adults or older teenagers bring stuffed toy animals to hospital during the investigation of suspected psychogenic non-epileptic seizures. In patients aged over 18 years those with a stuffed animal have a 3.21 times greater odds ratio of being diagnosed with psychogenic non-epileptic seizures (PNES) or both PNES and epilepsy rather than epilepsy alone [5]. Other authors have also found the teddy bear sign to be moderately specific but poorly sensitive for PNES [6].

In 2006, 14 dolls were introduced into two care homes in the North East of England. Three weeks later key workers were asked to identify the impact of the dolls on specific resident interactions with others. The overall impression of the 46 members of staff on the effect of the dolls was positive. Predictably there had been some problems including arguments between residents regarding ownership of the dolls, residents trying to feed their dolls and dolls being mislaid. A number of staff believed that the approach would be patronising and inappropriate but such impressions were reduced following the intervention. In particular all 14 residents with dolls were more amenable to personal care or exhibited no deterioration in pre-existing challenging behaviour. Likewise, agitation diminished or remained the same in all individuals studied. Residents talked to the doll or to others via the doll, some smiled at the doll and cradled it whilst walking with it. Specific behaviour included kissing or dressing the doll as well as cuddling or singing to it [7].

Doll therapy in residential care homes has identified that older individuals benefit from having to care for the dolls and feel that their ownership is important $[8,9]$.
When dolls and teddy bears are introduced into care homes the majority of residents would choose a doll over a teddy bear [10] however, the use of dolls is not without risk. Empathy dolls have been used to alleviate agitation in older orthopaedic patients but hazards such as prosthetic joint infections with Clostridium as a result of inadequate hygiene have been reported [11].

The holding of a teddy bear (rather than a cardboard box) to simulate interpersonal touch maybe beneficial in stimulating attention to errors such as almost falling. This however, maybe difficult to utilise in the rehabilitation setting [12].

In 2006 and 2009 Mulley and colleagues described Isaac's sign: handkerchief holding by older patients "beware a handkerchief in the hand, a handbag on the arm, food in the mouth, teeth in the jar, the hearing aid in the drawer and the artificial limb under the bed; all betoken a poor prognosis" [13]. Tissue holding may reflect physical symptoms such as cough, nasal symptoms, oral symptoms, sweating or vomiting although a variety of non-physical explanations including "habit" or "for comfort" also exist [14,15].

\section{Aim}

To investigate the cognition of older patients with teddy bears at the bedside and to identify any correlation with tissue holding, duration of hospital stay, final discharge destination and mortality.

\section{Settings and subjects}

Forty consecutive elderly patients in Acute Care of the Elderly Medicine wards in the South East of England were identified prospectively if they were seen to have a teddy bear within their bed space. Each patient was considered to be a research subject and the patient in the bed immediately to the left of these patients within the ward was designated as a control subject.

\section{Methods}

All subjects and controls had an abbreviated mental test score undertaken by a junior doctor who was unaware of the research being undertaken. The number of patients in each group who also held a tissue at the time of a consultant ward round was recorded.

Correspondence to: MA Gosney, Royal Berkshire NHS Foundation Trust, Elderly Care Medicine, London Road, Reading, Berkshire, RG1 5AN, United Kingdom, Tel: 0118-322-5474; Fax: 0118-322-6544; E-mail: m.a.gosney@reading.ac.uk

Received: October 03, 2017; Accepted: October 23, 2017; Published: October 25,2017 


\section{Results}

\begin{tabular}{|c|c|c|}
\hline & $\begin{array}{c}\text { Teddy Bear Owners } \\
\text { N=40 }\end{array}$ & $\begin{array}{c}\text { Controls } \\
\mathbf{N = 4 0}\end{array}$ \\
\hline AMTS & Range 0-6 & Range 5-9 \\
\hline & Mean 3.4 & Mean 7.5 \\
\hline & Median 3 & Median 7 \\
\hline Tissue Holding & $5(12.5 \%)$ & $0(0 \%)$ \\
\hline Mean Length of Stay & 62 days & 34 days \\
\hline From NH/RH & $12(30 \%)$ & $3(7.5 \%)$ \\
\hline Discharge to NH/RH & $16(40 \%)$ & $2(5 \%)$ \\
\hline Died whilst inpatient & $6(15 \%)$ & $1(2.5 \%)$ \\
\hline
\end{tabular}

\section{Conclusion}

The presence of a teddy bear correlates closely with cognitive impairment as measured by an abbreviated mental test score. Almost $13 \%$ of patients with a teddy bear were also tissue holders. No patient was able to identify the reason for their tissue holding. No control subject held a tissue at the time of study. All five patients with both a teddy bear and holding a tissue were from nursing homes. The mean length of stay of those individuals with a teddy bear differed considerably from those without. Ten patients who were living in the community prior to admission and who had either a teddy bear or teddy bear plus tissue holding were transferred to residential care on discharge. All six patients who died in the study group were residents of care homes prior to admission.

\section{Discussion}

As Bernard Isaac's reported that the handkerchief in the hand was a poor prognostic indicator so also is the presence of the teddy bear at the bedside. Those individuals with a teddy bear were more likely to be cognitively impaired and to a greater extent. They have a longer length of stay, less likelihood of returning to their original home and a greater mortality. Those teddy bear owners who also held tissues, whilst showing a trend to even worse prognosis numbers were too small in number for statistical analysis. The teddy bear may therefore be part of the daily routine of an older person with cognitive impairment. It should be carefully labelled to ensure that the older patient moving between wards does not lose this valuable support mechanism. Teddy bears cannot easily be sterilised and therefore the potential for them to be a source of sepsis must be considered and negated by regular cleansing and non-sharing with other patients. There is no formal evidence to suggest that agitation may be reduced in an acute elderly care medicine ward by the use of teddy bears but non-pharmacological methods such as this are always preferred and should be considered. The importance of the teddy bear in providing support and as a prognostic indicator should not be under estimated.

\section{References}

1. Ingersoll EW, Thoman EB (1994) The breathing bear: effects on respiration in premature infants. Physiol Behav 56: 855-859. [Crossref]

2. Ruiz-Casares M, Rousseau C, Currie JL, Heymann J (2012) 'I hold on to my teddy bear really tight': children's experiences when they are home alone. Am J Orthopsychiatry 82: 97-103. [Crossref]

3. Pesowski ML, Friedman O (2015) Preschoolers and toddlers use ownership to predict basic emotions. Emotion 15: 104-108. [Crossref]

4. Dalley JS, McMurtry CM (2016) Teddy and I get a check-up: A pilot educational intervention teaching children coping strategies for managing procedure-related pain and fear. Pain Res Manag 2016: 4383967. [Crossref]

5. Cervenka MC, Lesser R, Tran TT, Fortune T, Muthugovindan D, Miglioretti DL (2013) Does the teddy bear sign predict psychogenic nonepileptic seizures? Epilepsy Behav 28: 217-220. [Crossref]

6. Hoerth MT, Wellik KE, Demaerschalk BM, Drazkowski JF, Noe KH, Sirven JI, et al, (2008) Clinical predictors of psychogenic nonepileptic seizures: a critically appraised topic. Neurologist 14: 266-270. [Crossref]

7. Mackenzie L, James IA, Morse R, Mukaetova-Ladinska E, Reichelt FK (2006) A pilot study on the use of dolls for people with dementia. Age and ageing 35: 441-444. [Crossref]

8. Alander H, Prescott T, James IA (2015) Older adults' views and experiences of doll therapy in residential care homes. Dementia (London) 14: 574-588. [Crossref]

9. Shin JH (2015) Doll therapy: an intervention for nursing home residents with dementia J Psychosoc Nurs Ment Health Serv 53: 13-18. [Crossref]

10. James IA, Mackenzie L, Mukaetova-Ladinska E (2006) Doll use in care homes for people with dementia. Int J Geriatr Psychiatry 21: 1093-1098. [Crossref]

11. Subramanian B, Parsons H, Finner P, Townsend R (2014) Empathy dolls: are they a source of cross-contamination between patients? J Hosp Infect 87: 50-53. [Crossref]

12. Tjew ASM, Tops M, Heslenfeld DJ, Koole SL (2016) Effects of simulated interpersonal touch and trait intrinsic motivation on the error-related negativity. Neurosci Lett 617: 134-138. [Crossref]

13. Isaacs B (1992) The Challenge of Geriatric Medicine. Oxford, UK: Oxford University Press.

14. Collins DR, Saharia R, Watt R, Mulley GP (2009) Isaac's sign: handkerchief holding by older inpatients. Journal of the American Geriatrics Society 57: 2171-2172.

15. Watt R SA, Collins DR, Mulley GP (2006) Isaac's sign: Tissue holding in elderly inpatients. Age and Ageing 35: i59.

Copyright: (C2017 Gosney MA. This is an open-access article distributed under the terms of the Creative Commons Attribution License, which permits unrestricted use, distribution, and reproduction in any medium, provided the original author and source are credited. 